\title{
Türkiye'de Mahalle Yönetimlerinin Tarihsel Gelişimi ve Hukuki Statüsü
}

\author{
Vedat Yilmaz \\ Van Yüzüncü Y1l Üniversitesi \\ ORCID: 0000-0003-4624-9824
}

\author{
Mehmet Mecek \\ Afyon Kocatepe Üniversitesi \\ ORCID: 0000-0001-7173-8254
}

Öz

Mahalle yönetimi; demokrasinin gelişmesi, mahalle sakinlerinin kentin yönetim sürecine katıllmı ve yerel seviyedeki kamusal sorunların belirlenmesi ve çözüme kavuşturulması noktasında önemli bir araç olduğu tartışmasızdır. Türkiye'de 2012 yılında çıkarılan 6360 sayll “On Dört İlde Büyükşehir Belediyesi ve Yirmi Yedi İlçe Kurulması İle Bazı Kanun Hükmünde Kararnamelerde Değişiklik Yapılmasına Dair Kanun" sonrası büyükşehir belediyesi olan illerdeki köylerin mahalleye dönüştürülmesi ile birlikte mahalle sayısı artış göstermiştir. Günümüzde vatandaşların \%90'dan fazlası kentlerde yaşammı devam ettirmektedir. Dolaylsıyla vatandaşlar yaşamların belirli bir mahallede sürdürmektedir. Demokrasinin kü̧̈ük temel taşı ve gelişiminde önemli rol üstlenen bu topluluğun yönetilmesi hakkında geçmişten günümüze kadar genel bilgi ve temel sorunlarm dile getirilmesi gerekmektedir. Bu bağlamda çalışmada, öncelikli olarak; mahalle kavramı, mahalle yönetimi ve tarihsel gelişim süreci, günümüzdeki mahallenin hukuki statüsü, mahalle yönetimlerinin kurulması, kaldırlması ve organik yapısı, mahalle yönetimindeki aktörlerin görevleri ve yasal dayanaklarına ilişkin bilgiler verilmesinin yanında mahalle yönetiminin başı olan muhtarm seçimi ve muhtarm daha etkin ve verimli bir konuma getirilmesi adına ü̧̧ model öneri sunulmuştur.

Anahtar kelimeler: Mahalle, mahalle yönetimi, kent yönetimi, yerel yönetim, kamu yönetimi. 


\title{
Historical Development and Legal Status of Neighborhood Administrations in Turkey
}

\author{
Vedat Yilmaz \\ Van Yüzüncü Y1l Üniversitesi \\ ORCID: 0000-0003-4624-9824
}

\author{
Mehmet Mecek \\ Afyon Kocatepe University \\ ORCID: 0000-0001-7173-8254
}

\begin{abstract}
Neighborhood management; It is undisputed that it is an important tool for the development of democracy, participation of neighborhood residents in the city's governance process and the identification and resolution of public problems at local level. It issued 6360 number in 2012 in Turkey on "Fourteen in the province Metropolitan Municipality and Twenty-Seven County Law Amending the Decree on the Establishment and Some Law" after the metropolitan municipality, which has increased the number of districts with the transformation of the neighborhood of villages in the province. Nowadays, more than $90 \%$ of the citizens have been living in the urban areas in Turkey. Therefore, these citizens live in a certain neighborhood. From the past to the present, general knowledge and fundamental problems need to be addressed about the management of this community, which plays a major role in the development and the small mainstay of democracy. In this context, in the study, primarily; The concept of neighborhood, neighborhood management and historical development process, legal status of today's neighborhood, establishment, abolition and organic structure of neighborhood administrations, the duties and legal basis of the actors in neighborhood management, as well as the selection of the mukhtar of the neighborhood administration and bringing the mukhtar to a more effective and efficient position Three model proposals have been presented on behalf of.
\end{abstract}

Keywords: Neighbourhood, neighborhood governments, urban management, local management, public administration. 


\section{Giriş}

Mahalle insanların kent içinde topluluklar halinde yaşamlarını sürdürdükleri küçük yerleşim alanlarıdır. Mahallede düzen ve huzurun sağlanmasında mahallede yaşayanlar tarafından seçilmiş olan muhtar sorumludur. Muhtar aracılığıyla mahalle sakinleri mahalleleri ile ilgili sorun ve taleplerini ilgili merkezi yönetim ve yerel yönetim yetkililerine ulaştırabilmektedir. Ancak kendilerine ait bir kamu tüzel kişilikleri olmadıkları için ortaya çıkan sorunları doğrudan doğruya çözebilme imkânları bulunmamaktadır. Mahalle muhtarlıkları tüzel kişiliğe sahip olmadıkları için sözleşme yapamazlar, anlaşma imzalayamazlar, hukuki taraf olamazlar, personel istihdam edemezler ve en önemlisi bir bütçeye (mali imkânlara) sahip olamazlar. Bu nedenle bir yerel idare olmaktan ziyade yerel hizmet sunumuna aracıllk eden bir ara mekanizma olarak varlıklarını sürdürmektedirler. Bununla birlikte demokrasi ve katılım kültürünün geliştirilmesinde yerel yönetimlerin temel taşını oluşturmaktadır.

Mahalle muhtarlığı yönetimi muhtar ve azalardan oluşmaktadır. Muhtar; kamu adına mahalle sakinlerinin sorunlarını dinleyen ve sorunların çözümü noktasında merkezi idare ve yerel idareleri harekete geçirten bir ara mekanizmadır. Muhtarın işlerinde kendisine yardımcı olan ve yine mahalle halkı tarafından seçilen azalar görev yapmaktadır. Muhtar ve azalar mahalle sakinleri tarafından seçilerek beş yıllığ1na görev yapmaktadır.

Mahalle yönetimleri Osmanlı Devleti döneminde kentsel alan yönetiminin çekirdeğini oluşturmaktaydı. Günümüzde belediye yönetimlerinin gördüğü işlevlerin büyük bir çoğunluğu o dönemde mahalle esasında gerçekleştirilmekteydi. 1908 yılından itibaren ise mahallenin bu işlevleri ortadan kaldırılmıştır. Günümüzde mahalle muhtarları ağırlıklı olarak tebligat işlemlerine yardımcı bir kamu görevlisi ve sosyal yardımlarda mahalle halkını tanıyan bir aracı konumuna hapsedilmiştir. Bununla birlikte katılım kültürünün geliştirilmesinde önemli bir rol üstlenmesi nedeniyle de yakın zamanda yeni hukuki düzenlemelere konu edilmesi beklenilmektedir. Mevcut bir idari unsurun yeniden düzenlenmesi ve zamanın şartlarına göre modernize edilebilmesi için öncelikle mevcut durumunun çok iyi bir şekilde analiz edilmesi ge- 
rekmektedir. Mevcut durumun anlaşılması da tarihsel süreci ile birlikte ele alınmasıyla tam olarak gerçekleştirilebilecektir.

Çalışmada mahalle kavramı ve tarihsel gelişim süreci içerisinde ele alınarak günümüzdeki hukuki statüsüne değinilmiştir. Türkiye'nin yönetim yapısındaki yeri, temel görevleri, organları hakkında bilgi verilmiş olup, ayrıca muhtar ve azaların özlük hakları ile cezai sorumluluklarına da yer verilmiştir. Bu bağlamda yeni olası yasa çalışmaları için mevcut durum analiz edilerek bir alt form oluşturulmaya çalışılmiştır.

\section{Mahallenin Kavramsal - Hukuki Çerçevesi ve Tarihsel Dönüşümü}

Mahallenin kavramsal ve hukuki çerçevesiyle birlikte mahallenin tarihsel gelişim ve dönüşüm süreçlerine ilişkin kısımlar aşağıda sunulmuştur.

\section{Mahallenin Tanımı ve Tarihsel Gelişim Süreci}

Mahalle kelime olarak bir yere inilmesi, yerleşilmesi, konumlanması, anlamlarını ifade eden hall (halel ve hulûl) kökünden türetilmiştir (Yel ve Küçükaşçı, 2003, s.323). Mahall kelimesi ile de aynı köke dayanmaktadır. Akademik yazında klasikleşen bir tanıma göre mahalle; birbirini tanıyan ve bir ölçüde birbirlerinin davranışlarından sorumlu olan kişilerin yaşadığ1 yer ya da aynı ibadethanede (mescit, cami, vd.) ibadet eden cemaatin, aileleriyle beraber ikamet ettikleri coğrafi alandır (Ergenç, 1984, s.69). Bu durumda mahallelerin ayırt edici özelliği, kendisini oluşturan kişilerin mensubu oldukları din olmuştur. Cami ve mescit gibi ibadethaneler burada esas olmakla birlikte; kalenderhâne, âsitane, tekke, zaviye, dergâh, vd. gibi herhangi bir tarikata mensup kişilerin birlikte yaşadıkları, konakladıkları, ibadet ve dini tören yaptıkları inanç içerikli yapılar da şehirlerde mahallelerin oluşmasına etki etmiştir (Kuban, 1968, s.60; Akşit, 2014, s.69).

Bizans hâkimiyetinden Türk hâkimiyetine geçildiği sıralarda Anadolu şehirlerinde Ermeni, Rum gibi gayrı Müslim tebaaya mensup etnik gruplar birbirlerinden ayrı mahallelerde yaşıyorlardı. Selçuklu devleti döneminde de bu durum önemli ölçüde devam etmiştir. Ancak Sivas gibi dönemin uluslararası ticaret merkezi olan ve şehirlerde karışık halde yaşanılan mahalle yapılanmaları da görülmeye başlanmıştı (Demir, 2005, s.115116). Ancak genel ağırlık mahallelerin inanç ekseninde ayrı ayrı teşekkül ettirilmesidir. Çoğulculuğa imkân veren ve İslâmî anlayışa uygun olarak 
çoğulculuğa imkân tanıyan din/mezhep esaslı Yahudi, Hıristiyan ve Müslüman mahalleleri, bireylere psikolojik olarak yüksek bir aidiyet duygusu kazandırmakta, asimile olmadan kendi inanç ve değerleriyle uyumlu kimliklerini pekiştirmeye yardımcı olmuştur (Braudel, 1993, s.447). Selçuklu kentleri bir iç kaleyle şehrin tamamını çevreleyen surlardan oluşmaktaydı. Kapalı kent biçiminde olan bu şehirlerin bir kısmı 12. yüzyılın ortalarından itibaren sur dışına taşarak açık kent şekline gelmiştir. Kentin fethinden itibaren Türkler ilk olarak şehir merkezinde imar edilen cami ve mescit gibi yapıların etrafına yerleşmişlerdir (Akşit, 2014, s.70). Örneğin bu dönemde Konya'da Türkler sur içerisinde, gayri Müslim kişiler de sur dişında bulunan mahallelerde yaşıyorlardı (Baykara, 1985, s.46-48) Ancak nüfus artışı ve bazı sosyo-ekonomik gelişmeler sonucunda Türkler de kale dışında mahalleler oluşturmayı sürdürmüşlerdir.

Selçuklu döneminde kentler; siyasi, idari, ekonomik ve kültürel merkezler olmasından dolayı halk; idareciler, ilim ve din adamları, tüccar ve sanatkârlar olmak üzere birbirlerinden farklı toplumsal sınıflara ayrılmıştı (Akşit, 2014, s.76). Sosyal ve fiziki özellikleriyle beraber mahalle idari bir birim, merkezi idarenin bireyler ile ilişki içerisinde olabilmesine olanak tanıyan bir bağlantı kurumuydu (Tanyeli, 1987, s.164). Bu doğrultuda mahalle dini ve kültürel bir birim olduğu gibi, idari ve mali bir birim olarak da değerlendirildiği görülmektedir (Ortaylı, 2013, s.53). Osmanlı kentlerinde her ne kadar cami ve Müslüman toplumun ön planda olduğu görünse de, genel olarak gayrimüslim halk ta aynı şehrin bir parçası olarak yaşamını yüzlerce yıl devam ettirmiştir (Üstündağ, 2005, s.158). Ancak kent içerisinde inanç ve inanca dayalı toplumsal yaşantılarını daha rahat ve özgür sürdürebilmek, asimile olmamak, daha etkin bir dayanışma sağlayabilmek ve hukuk kurallarının daha belirgin bir şekilde uygulanmasını sağlayabilmek gibi birçok maslahat açısından farklı toplulukların ayrı ayrı mahalleler oluşturduğu görülmektedir. Selçukluların Abbasi ve Emeviler'den devraldıkları bir yönetim anlayışı mirası olan bu uygulamanın benzer versiyonları Selçuklular öncesi Anadolu kent yaşamında da mevcut olduğu görülmektedir. Bu durum özellikle inanç eksenli kent birimlerinin (mahallelerin) kurulmasının tarihsel derinliğini ortaya koymaktadır. Ancak en etkin olmasına rağmen, mahallerin kurulmasındaki tek ölçüt olmadığı da unutulmamalıdır.

Osmanlı döneminde mahalle; asayişin sağlanması, suçluların tespit edilmesi, bayındırlıkla ilgili bazı yükümlülüklerin yerine getirilmesi, kamu görevlilerinin kontrol edilmesi, bazı durumlarda kamu hizmetlerinin fiilen yerine getirilmesi, mahallede yaşayan diğer bireylerle dayanışma 
içerisinde bulunulması, mahalle hakkında alınacak kararlara iştirak edilmesi, bir kısım vergilerin hesaplanması, vergilerin tahsil edilmesi gibi muhtelif görev ve sorumlulukların yerine getirildiği en küçük yönetsel birimdir. Osmanlı mahallelerinin yerleşim ve yapılaşma politikaları spekülatif ve ahlâk dışı yaklaşımları önleme esasına dayanmaktaydı. Bu iskân politikasının en önemli örneklerinden birisi, bekâr nüfusun mahallelerde bulundurulmamasına gayret edilmesidir. İstanbul'da çalışmak için kente gelen bekâr işçiler, merkezi iş bölgelerindeki bekâr hanlarında barındırılarak bir tür gözetim altında tutulmuştur (Düzbakar, 2003, s.97-100). Osmanlı şehirlerinde mahalle halkı hakkında dedikodu yapmak veya alkol tüketmekle suçlananlar, mahalleden söz konusu duyarlıklar ve dayanışma ruhu ile atılmaktaydı. Bu durum bekârlar ve yabancılar için mahalleleri cazip olmaktan çıkarmaktaydı. Mahalle halkının sevinci ve üzüntüsü de ortaktı. Ölüm, hastalık, kaza, evlenme ve bayram gibi olay ve durumlarda bir bütün olarak, birlikte gerçekleştirilirdi (Doğan, 2002, s.19). Osmanlı imparatorluğunda pek çok kamu hizmetinin vakıflar ve lonca teşkilatları gibi sivil kuruluşlar tarafından yürütüldüğü bilinmektedir. Aynı durum mahallenin ihtiyaçlarının karşılanmasında da söz konusu olmuştur. Mahallelerde bulunan "Avarız Sandığı" ya da "Avarız Vakıfları", mahalle sakinlerinin bağışları, zenginlerin tasarrufları, adak ve sadakalarla desteklenen fonlar aracılığıyla karşılanırdı. Burada biriken paralar, imam ve mütevelli vasıtasıyla maddi durumu iyi olmayanlara, mahallelinin birbirlerine kefil olmaları koşuluyla borç olarak verilmekteydi. Yine mahallede ekonomik olarak yaşamını sürdürmede sorun yaşayanların sorunlarını gidermek, yoksul ve kimsesiz olanların cenazelerinin kaldırılması, avarız vergilerini ödeyemeyenlere yardımcı olunması gibi insani amaçlar doğrultusunda da kullanılırdı. Ayrıca, mahalledeki kaldırımların bakımının yapılması, su masrafları, okul ve camilerin bakım, onarım ve ısıtılmasıyla imam, müezzin ve bekçi ücretlerinin ödenmesi gibi imar işleri de yine avarız sandığında toplanan paralardan temin edilmekteydi (Özbilgen, 1987, s.83). Selçuklu ve de özellikle Osmanlı şehirlerinde günümüz belediyecilik hizmetleri zamanın koşullarına göre mahalle teşkilatları tarafından karşılandığı için buralarda belediye teşkilatının (idaresinin) bulunmaması, bazı batılı araştırmacıların zannettiği gibi bir eksiklik meydana getirmemiştir (Demirci, 2003, s.145). Ancak sanayi devrimi sonrasında gelişen ve dönüşen Avrupa kentlerindeki gibi çok yönlü ve türde belediye hizmetleri eş zamanlı olarak Osmanlı kentlerinde sunulamamıştır. Bu durumun en önemli nedenleri duyulan ihtiyaçların farklılıkları, kaynak yetersizlikleri ve uzman personel istihdamının sağlanamamasıdır. 


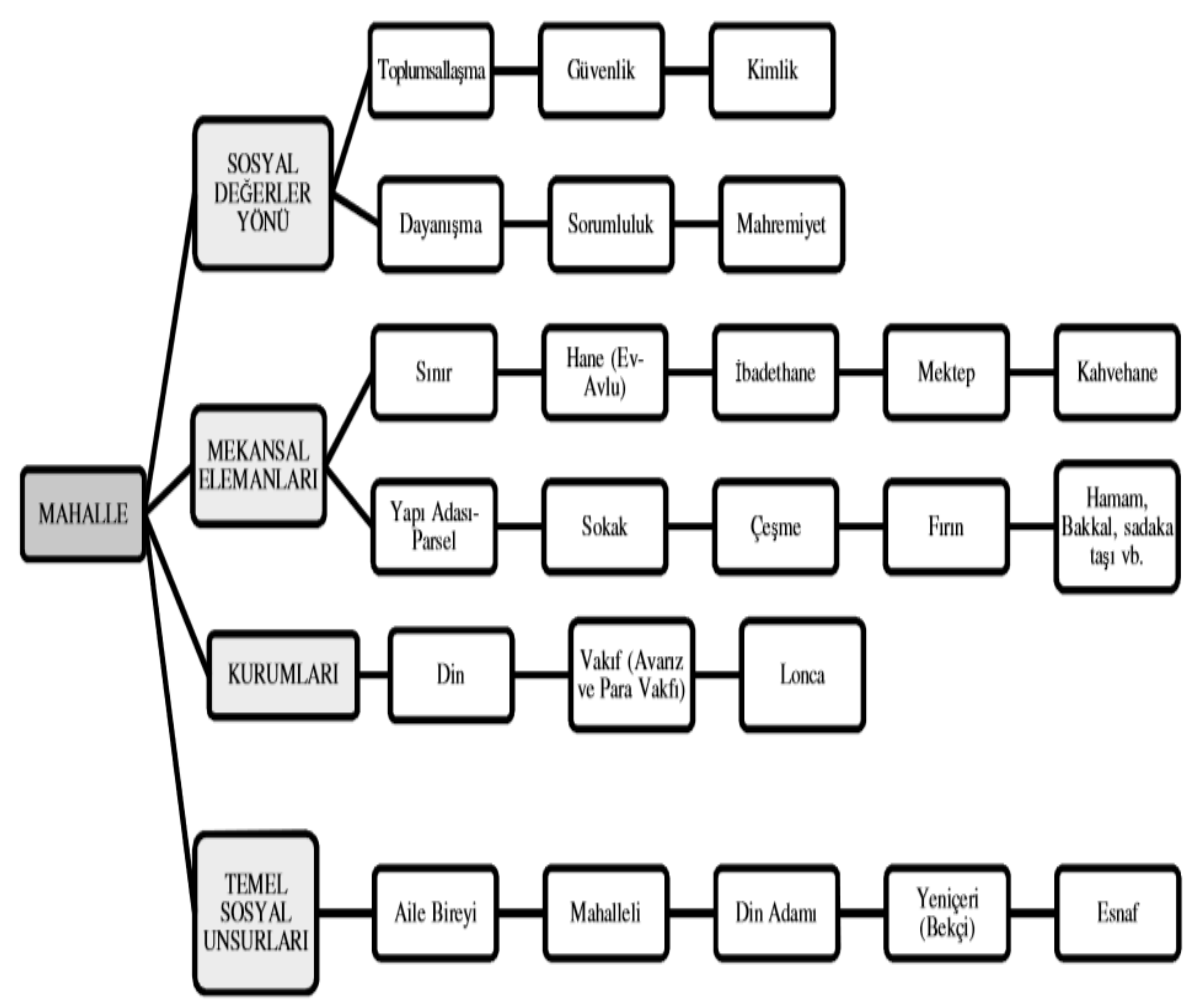

Şekil 1. Osmanlı Devleti'nde (Tanzimat Öncesi Döneminde) Mahallenin Temel Bileşenleri (Kaynak: Çabuk ve Demir, 2012, s.142)

II. Mahmut döneminde (1808-1839) gerçekleştirilen reformlar ile kadıların imamlar üzerinde bulunan hiyerarşisi yavaş yavaş ortadan kalkmaya başlamıştır. 1826'da kent güvenliği, kolluk ve bazı belediye hizmetlerinde görevli olan yeniçeri ocağının kaldırılması ile birlikte ortaya çıkan/çıkacak boşluğu doldurmak amaciyla her mahalle için bir muhtar ve ihtiyar heyeti seçilmesi kuralı ihdas edilmiştir. Mahalle muhtarlığı teşkilatı ilk defa 1829 yılında İstanbul'da faaliyetlerine başlamıştır. Ancak "muhtar" kelimesinin 1815 tarihli bir belgede kullanıldığ tespit edilmiştir. Hatta 1815 öncesinde de zaman zaman "köy veya topluluk yöneticisi-temsilcisi" anlamında kullanılmasına da rastlanılmaktadır (Özdemir, 1986, s.172). Ancak bu durum mahalle muhtarlığı teşkilatının varlığına değil, muhtar kavramının yönetici/temsilci anlamında genel olarak kullanıldığını ortaya koymaktadır (Bayramoğlu, 2000, s.159).

19. yüzyıl ıslahatları ile mahalle ve köylerde muhtarlık teşkilatları oluşturulmaya başlanılmasıyla imam ile muhtarın karşılaştırılmasında muhtar 
daha yetkili bir idareci konumunu almıştır. Muhtar mahallenin tamamının kefili, imam ise muhtarın kefiliydi. Mahallelerin varlığı çok eski dönemlere kadar uzanıyor olsa da mahalle muhtarlıkları teşkilatının kurulması Osmanlı dönemine rastlamaktadır. Osmanlı Devletinde ilk mahalle muhtarlığı teşkilatları başkent İstanbul'da kurulmuştur. İstanbul haricinde ise bilinen ilk muhtarlık teşkilatı 1833 yılında Kastamonu Sancağında kurulmuştur. Taşköprü âyanının halka zulmettiği yönündeki şikâyet sonrası zamanın Kastamonu Mütesellimi tarafından mahalle muhtarlı̆̆ı teşkilatları kurdurulmuştur. İstanbul'da mahalle muhtarları atamayla göreve gelirken, Kastamonu Sancağı içerisindeki mahalle muhtarları seçim yoluyla göreve gelmişlerdir. Halk tarafından muhtar-1 evvel (birinci muhtar) ve muhtar-1 sâni (ikinci muhtar) seçilerek göreve getirilmişlerdir. Kastamonu Sancağı içinde muhtarlık teşkilatları kurulmasını uygun bulan sultan II. Mahmut'un emriyle tüm ülke genelinde mahalle muhtarlıkları kurdurulmuştur (Çadırcı, 1970, s.410-412). Bu dönemde daha önce imamlar tarafından yerine getirilen birçok temel görev artık mahalle muhtarları tarafından ifa edilmeye başlanmıştır. Muhtarların temel görevleri şunlardı (Çadirc1, 2007, s.19-20):

- Mahallenin asayiş ve genel düzenini sağlamak,

- Mahalle dişından mahalleye gelenlerin mürur tezkeresi"ni kontrol etmek, kefil bulunması halinde mahallede ikametine izin vermek, tezkeresi olmayanları mahallede barındırmamak,

- Mahalle dişında bir yere seyahat (yolculuk) etmek isteyenlere durumlarını (kimlik bilgileri, seyahat ve konaklama bilgileri, eşkali, vs.) ayrıntılı bir şekilde ortaya koyan mühürlü pusula (mürur tezkeresi) vermek,

- Mahallede doğan, yeni taşınan, evlenen kişileri mahalle defterine kaydetmek ve mahallede ölen, yiten, başka mahalleye taşınanları mahalle defterinden silerek nüfus hareketlerini günlük olarak defter nazırina bildirmek,

- Mahallede meydana gelen ölümler sonrası veraset intikali işleriyle ilgilenmek,

- Vergilerin paylaştırılmasına (tahakkukuna) ve toplanmasına (tahsiline) yardımcı olmak. Gerek duyulduğunda temsilci olarak meclis-i şer'e katılmak. Bağlı bulunan kasaba ya da şehrin her altı ayda bir hazırlanan gider defteri çalışmalarına mahallesini temsilen katkıda bulunmak. Mahallesinin gelir ve giderlerini gösteren hesap defterini tutmak ve mahalle payına düşen vergilerin dağıtılmasında (tahakkukunda) mahalle imamı ile birlikte meclis-i şer'de çalışmak. 
Mahalle ve köy muhtarları 1831 nüfus sayımından hemen sonra sancaklarda kurulan Defter Nazırları'na bağlıydılar. Defter Nazıdarı da yine bu tarihte İstanbul'da ihdas edilmiş olan Ceride Nezareti'ne bağlıydı. Fakat muhtarların denetimi sancağın idari işlerinden sorumlu mütesellimler tarafından yürütülüyordu. Halk muhtarlardan memnun değilse imamları ve mahallenin ileri gelenleri vasıtasıyla mütesellime şikâyet edebiliyordu (Çadırc1, 2007, s.19-20). Tanzimat'a kadar muhtarların görevleri mütesellim tarafından denetlenirken, bu tarihten sonra muhassillar ve zaptiye amirleri tarafından denetlenmeye başlanmıştır. 1864 Vilayet Nizamnamesi'nden sonra muhtarların görev onaylama yetkisi Babıâli'den alınıp valilere verilmiştir (Ortaylı, 2000, s.108-110).

1864 tarihli Vilayet Nizamnamesi'nde (md.5), kasaba ve şehirlerde en az elli hane bir mahalle olarak kabul edilmiştir. Ayrıca aynı maddenin sonunda "...her bir mahalle bir kariye (köy) hükmünde bulunacaktır (hükmündedir)", ibaresine yer verilmektedir. Bu hüküm ile mahalle muhtarlıkları köy muhtarlıkları ile aynı hukuki statüde yer almışlardır. Daha doğrusu mahallelerle ilgili ayrıca düzenlemeye gidilmeden, köy (kurâ -kariye) muhtarlığ1 için öngörülen uygulamalar (yöneticilerin belirlenmesi, göreve gelmesi, vs.) mahalleler için de aynen kabul edilmiştir. Mahallelerde her dini cemaat için 2 muhtar (20 haneden az mahallelerde bir muhtar) seçilmesi öngörülmüştür (md.58). Ayrıca mahallelerde 3 ila 12 arasında ihtiyar meclisi üyesinin seçilmesi öngörülmüştür. Mahallelerdeki dini liderler (imam, papaz, haham, vd.) ihtiyar meclislerinin doğal üyeleri olduğu kabul edilmiştir (md. 62). Muhtar ve ihtiyar heyetinin görev süresi 1 yıl olarak kabul edilmiştir (md. 75).

Mahalle muhtarlarının seçilmesi ve görevlerini ifa etmesi daha önceden (1829) gerçekleştirilmiş bir uygulama olsa da mahalle muhtarlıklarının kurumsal olarak örgütlenmesi 1864 yılında gerçekleştirilmiştir. Özellikle 1864 nizamnamesiyle muhtarlara yardımc bir konumda ihtiyar meclislerinin kurulması mahalle muhtarlıklarını daha kurumsal bir hale getirmiştir (Bal vd., 2012, s.22). Mahalle muhtarı ve ihtiyar meclisi üyesi (doğal üyeler dışındaki) seçilebilmek için bazı şartlar aranmaktaydı. Bu şartlar şunlardır (md. 68):

- Osmanlı uyruğundan olmak (vatandaşlık şartı)

- Mahalle ile ilgisinin bulunması (ikamet şartı)

- En az 30 yaşında olunması (yaş şartı)

- Devlete en az 100 kuruş vergi ödemiş olması (mali şart) 
Mahalle muhtarı ya da ihtiyar meclisi üyeliği için yukarıda belirlenen şartların yanı sıra seçmen olabilmek için de bazı şartlar öngörülmüştür. Daha yalın bir ifadeyle muhtar ya da ihtiyar meclisi seçebilmek (oy kullanabilmek) için aranan şartlar şunlardır (md. 67):

- Osmanlı uyruğundan olmak (vatandaşlık şartı)

- Mahalle ile ilgisi bulunması (ikamet şartı)

- En az 18 yaşının doldurulmuş olunması (yaş şartı)

- Devlete en az 50 kuruş vergi verilmesi (mali şart)

İhtiyar meclislerinin kurulması esasen 1826 yılında düzenlenmiştir. Ancak etkin olarak düzenlenerek göreve başlamaları Ortaylı (2000)'ya göre 1864 tarihli Tuna Vilayeti Nizamnamesiyle gerçekleştirilmiştir. 1287 (1869-1870) tarihli “İdare-i Umumiye-i Vilayet Nizamnamesi" mahalle yönetimlerini hem merkezi yönetime karşı hem de yerel işlere yönelik görevleri daha teferruatlı olarak düzenlemiştir. 1871 tarihli Osmanlı vilayet kanununda mahalle, asgari 50 haneden oluşmuş yerleşim birimi olarak tanımlanmıştır. 1908 yılında İttİhat ve Terakki Partisinin göreve gelmesinin ardından mahalle teşkilatları işlevsiz bir hale dönüştürüldüğünden, şehir yaşamındaki bu dinamizm ve oto kontrol sistemi ağır ağır etkinliğini kaybetmiştir. 1908'de ilan edilen İkinci Meşrutiyet' in ayrı bir önemi bulunmaktadır. İkinci Meşrutiyetle men-i mürur uygulamasının kaldırılması sonrası muhtarın asayiş ve güvenliğin sağlanması amacıyla yapmış olduğu görevler elinden alınmıştır. 1913'de çıkarılan İdare-i Umumiye-i Vilayet Kanununu ile yasal olarak da bu görevler muhtardan alınmıştır. Ancak bu Kanun ile mahalle muhtarlı̆ 1 yerine yeni bir yönetim birimi kurulmadığı için merkezi yönetimle ilgili bazı görevleri mahalle seviyesinde icra edecek idareci kalmamıştır. Bu nedenle mahalle muhtarları hükümetlerin izni ile eski görevlerini sürdürmeye devam etmişlerdir. Osmanlı zamanında yasal dayanağını kaybeden mahalle muhtarlığ ${ }_{1}$ Cumhuriyet'in ilanından sonra dahi 1934 yılına kadar varlığını sürdürmüştür (Derbil, 1959, s.325-326; Bayramoğlu, 2002, s.160; Arıkboğa, 1999, s.114; Eryılmaz, 1988, s.474). Mahalle muhtarlığ yasal dayanağı olmaksızın yaklaşık 10 yıl Meşrutiyet, 10 yıl da Cumhuriyet döneminde varlığını sürdürmüştür (Bulut ve Kara, 2011, s.8). Her ne kadar akademik yazında mahalle muhtarlıklarının varlıkları 1934 yılına kadar fiilen devam ettirildiği görüşü hakim olsa da, esasen 1933 yılında mahalle muhtarlıkları 2295 sayılı Kanunla fiilen de uygulamada kaldırılmış ve görevleri 15436 sayılı tüzük ile merkezi idare ve belediyeler arasında paylaştırılmıştır. Devlet belediyelerin oluşumunu tamamladığını düşünerek ve merkezi idarenin taşradaki birimlerinin daha etkin bir hal aldığını kabul ederek hukuki olarak mevcut 
olmayan, ancak fiilen varlığını devam ettiren mahalle muhtarlıklarına olan ihtiyacın kalmadığını öngörerek 2295 sayılı kanunla mahalle muhtarlıklarını tamamen kaldırmıştır (Eryılmaz, 1988, s.474; Arıkboğa, 1999, s.112). Mahalle muhtarının ve ihtiyar heyetinin yürüttüğü görevler belediyeler ve bağlı birimleri (özellikle zabıta birimine) ile diğer kamu idare ve kurumlarına verilmiştir. Yine 1934 tarihinde çıkartılan uygulama yönetmeliğiyle bu görevlerin kimler tarafından ve ne şekilde yürütüleceği belirlenmiştir. Ancak mevcut kanun ve yönetmeliğin uygulamasında aksakların ortaya çıkması nedeniyle mahalle muhtarlıklarının varlığına duyulan ihtiyacın sona ermediği anlaşılarak 15/04/1944 tarih ve 4541 sayılı resmi gazete ile yürürlüğe giren "Şehir ve Kasabalarda Mahalle Muhtar ve İhtiyar Heyetleri Teşkiline Dair Kanun"'la mahalle muhtarlıkları yeniden kurulmuştur. İlgili kanun bazı değişikliklere uğramakla birlikte halen yürürlüktedir.

Mahalle muhtarlıkların kurulması, organları, görev ve sorumlulukları gibi hususların 4541 sayılı yasada düzenlenmiş olmasına rağmen, mahalle muhtarlığ1 ve ihtiyar heyeti seçimleri 18/01/1984 tarihli ve 2972 sayılı "Mahalli İdareler ile Mahalle Muhtarlklar ve İhtiyar Heyetleri Seçimi Hakkında Kanun"da düzenlenmiştir. Diğer taraftan mahalle muhtarlarının görevleri büyük ölçüde 4541 sayılı "Şehir ve Kasabalarda Mahalle Muhtar ve İhtiyar Heyetleri Teşkiline Dair Kanun"a dayanmakla birlikte, 03.07.2005 tarih ve 5393 sayılı "Belediye Kanunu"'da bu konuda bazı temel hükümlere yer vermiştir.

\section{Mahallenin Hukuki Statüsü}

5393 sayılı kanunla (md.3/d) yapılan tanım mahallelerin; oluşma şekli, varlık amacı, hukuki yapısı, statüsü, vd. unsurlar açısından tarihi kimliğinden daha farklı bir yapıya büründügünü (dönüştüğü) göstermektedir. Bu değişim ve dönüşümün daha iyi anlaşılabilmesi açısından tanım üzerinden bazı temel çıkarımlarda bulunması mevcut durumun daha net bir şekilde kavranmasına katkı sağlayacaktır.

Mahalle ile ilgili yapılan tanımda; mahallelerin belediye sınırları içerisinde yer alabilen, dolayısıyla kentsel alan yönetimi içerisinde değerlendirilebilecek bir yönetsel yapı olduğu ifade edilmektedir. Buradan hareketle kırsal alan yönetimi olan köy muhtarlıkları sınırları içerisinde mahalle muhtarlıkları ihdas edilmesi söz konusu değildir. Tanımdan elde edilen ikinci bir çıarımda mahallelerin "ihtiyaç ve öncelikleri benzer özellikler gösteren" ve aralarında "komşuluk ilişkisi bulunan" kişilerden oluştuğudur. İhtiyaç ve önceliklerin benzerliğinin tespitinde ise aynı dine, mezhe- 
be, meşrebe, tarikata, cemaate, mesleğe, etnik kökene, ortak kültüre, geçmişe vb. mensup (sahip) olma özelliği aranmamaktadır. Coğrafi birlikteliğe esas ortak ihtiyaçlar ve komşuluk ilişkisi esas alınmaktadır. Bu dönüşümün gerçekleşmesinde kent nüfusunun ve yoğunluğun artması sonucu mahallelerin homojen yapısının dönüşüme uğrayarak heterojenleşmesi önemli bir etken olmuştur.

Belediye kanununda (md.3/d) yapılan tanımda mahallenin "idari birim" olduğu ifade edilmektedir. Ancak bu idari birimin hangi kamu idaresine bağlı olduğu ve hukuki statüsünün ne olduğu gibi hususlara ayrıca ve açıç̧a yer verilmemiştir. Mahallelerin belediye sinırları içerisinde tesis edilmesi, mali yetersizlikleri nedeniyle belediyelerin bütçe imkânları ölçüsünde ayni ve nakdi yardım yapması, vb. nedenlerle ağırlıklı olarak belediyeye bağlı bir idari birim olarak değerlendirilmesine neden olmaktadır. Ancak mahalleleri belediyeler dişında ilişkilendiren yazarlar da bulunmaktadır. Örneğin Derdiman (2015), mahalleleri "yerel yönetim benzeri merkezden yönetim teşkilatı (mahalle idaresi)" olarak nitelendirmektedir. Bulut (2001)'a göre mahallelerin tek başına bir yerel yönetim birimi ya da merkezi idareye bağlı bir alt birim olmadığı, bu nedenle de mahallelerin "hem merkez, hem de yerel hizmet amaçlarn çerçevesinde örgütlenen bir ara kurum olduğınu" ifade etmektedir. Daha yalın bir ifadeyle mahalle yönetimlerini merkezle yerel arasında bir köprü ve yönetenle yönetilenler arasındaki ilişkiyi sağlayan bir ara kurum olarak görmektedir. Ancak bu ifade de mahalle muhtarlığının yönetim yapısı içerisindeki konumunu açıça ortaya koymamaktadır.

Mahallelerin hukuki statüsü ile ilgili olarak yukarıda bahsedilen iki temel görüşün ve bu görüşlere ait dayanaklarının ele alınması mahalle yönetimlerinin hukuki statüsünü ve yönetim şeması içerisindeki konumunun daha iyi analiz edilebilmesi açısından oldukça önemlidir. Bu nedenle bu iki görüşü destekleyecek temel argümanlar (hukuki durumlar) belirlenerek tek tek ve kısaca incelenecektir. Bu bağlamda mahalle muhtarlıklarını yerel yönetimlerden uzaklaştırıp, merkezi idare içerisinde değerlendirilmesine neden olan/olabilecek bazı hukuki durumlar şunlardır;

- Tüzel kişiliğinin olmaması ve ayrı bir kamu idaresi/kurumu olarak değerlendirilememesi,

- Kentsel alan yönetimi olan belediyelerle organik/teşkilatsal bir bağlarının bulunmaması,

- Görev ve sorumlulukları ile ilgili denetimin yerel idareler yerine, kaymakamlıklarca (merkezi idare birimlerince) gerçekleştirilmesi, 
- Temel görevlerinden büyük bir çoğunluğunun merkezi idare birimlerinin mahalle düzeyindeki hizmetlerinin ifasında yardımcı olunması şeklinde belirlenmesi,

- Mahalle organlarının seçiminde adaylık usulünün olmaması ve siyasi partilerin bu kişileri aday gösterememesi,

- Muhtar maaşlarının yerel yönetimlere ait bütçeler yerine genel bütçeden ödenmesi.

Mahalle muhtarlıklarının tüzel kişiliği bulunmamaktadır. Bu nedenle de tüzel kişiliğe bağlı hak/fiil ehliyetine, bağımsız bir bütçeye (özerk mali yapıya) ve kendine özgü personel istihdamına sahip olması düşünülemez. Ancak istisnai olarak Vergi Usul Kanununa (md.49/b) emlak vergisine ilişkin bedel ve değerlerin kesinleşmesi sürecinde mevcut olan takdir komisyonu kararına karşı dava açma yetkisi verilmiştir (Derdiman, 2015, s.269). Tüzel kişiliğin bulunmamasının daha önemli bir sonucu da mahalle muhtarlıklarının "devlet, il özel idaresi, belediye ve köy" gibi bir "kamu idaresi" ya da hizmet yönünden yerinden yönetimler olan "kamu kurumu" olarak düşünülmesinin söz konusu olamayacağıdır. Ancak bunların içerisinde yer alan ya da bunlardan herhangi birisiyle/birkaçıyla ilişkili bir alt idari birim olabileceğidir. Her ne kadar belediyelerle mahalle muhtarlıklarının doğrudan bir organik (teşkilatsal/örgütsel) bağları bulunmasa da bu durum merkezi idareyle bir organik bağlarının bulunduğunu da ortaya koymaz. Mevzuatta bu yönde hiçbir hukuki bağ olarak nitelendirilebilecek bir norm bulunmamaktadır.

Mahalle muhtarlıklarının denetimi daha spesifik bir ifadeyle muhtar ve ihtiyar heyetinin görevlerini yapmamaları halinde ikaz edilmesi ve ikaza rağmen olumsuzluğun devam etmesi halinde bağlı bulunulan kaymakam veya vali tarafından görevden el çektirilecekleri 4541 sayılı yasada (md.18) öngörülmektedir. Ancak bu durum mahalle yönetimleri ile merkezi idare yöneticileri arasında hiyerarşik bir ilişki kurulması açısından tek başına yeterli bir durum değildir. Her ne kadar seçilmiş yerel idarecilerin görevden azledilmesi yani görevlerinin tamamen sona ermesi idari yargı mercileri (Danıştay) tarafından gerçekleştiriliyor olsa da açı̆̆a alınmalarında ya da görevlerini ifa etmeme durumunda uyarılmalarında merkezi idare içerisindeki birimler (İçişleri Bakanlığı, Çevre ve Şehircilik Bakanlığı, Valilikler) aktif rol oynamaktadırlar. Ayrıca yapılan işlemlerin denetlenmesinde kaymakamlara tanınan denetim yetkisi yine köy kanununda da (md.40) mevcuttur. Nasıl ki bu durum köy muhtarları/muhtarlıkları ile kaymakam/kaymakamlık (merkezi idare) arasında bir hiyerarşinin yani 
organik bağın kurulması düşüncesini ortaya koymuyorsa aynı durum mahalle muhtarlıkları için de söz konusu olmaktadır.

Mahalle muhtarlıklarının genel görev ve sorumluluklarının büyük ölçüde kaymakamlık ve bağlı birimlerin mahalle düzeyindeki görevlerini yerine getirmelerinde yardımcı olmaları yönünde olduğu görülmektedir. Ancak bu durum mahalle muhtarlıklarının kaymakamlığa bağlı bir alt idari birim olmasını gerektirmez. Zira köy kanununda yer alan köyün ve köy muhtarının görev yetki ve sorumlulukları da genel olarak bu doğrultudadır. Oysaki köy muhtarlıklarının bir yerel yönetim birimi oldukları başta anayasa ve köy kanunu olmak üzere hukuki olarak açıkça ortaya konulmuştur. Bu hususla ilgili herhangi bir tartışma da bulunmamaktadır. Mahalle organlarının seçiminde adaylık usulünün olmaması (2972/md.31) ve siyasi partilerin bu kişileri aday gösterememesi yine köy organları (muhtar ve ihtiyar heyeti) için de geçerlidir. Mahalle muhtarı maaşlarının yerel yönetimlere ait bütçeler yerine genel bütçeden ödenmesi durumu köy muhtarları için de geçerlidir. Dolayısıyla tüm bu açıklamalar doğrultusunda mahalle muhtarlıklarını merkezi idarenin bir parçası olarak düşünmek isabetli bir yaklaşım olmayacaktır.

Mahalle muhtarlıklarını merkezi idarenin bir parçası ya da merkezi idareye çok daha yakın olduğunu ortaya koyan yaklaşımların yanı sıra mahalleleri belediyeler (yerel yönetimler) içerisinde özerk bir idari birim olarak gören yaklaşımlar da bulunmaktadır. Mahalle yönetimlerini belediyeler içerisinde bağımsız ayrı bir idari birim kabul edilmesine neden olan/olabilecek başlıca hukuki durumlar şunlardır;

- Tanım ve vasfının az da olsa belediye kanunu içerisinde yapılmış olmasi,

- Kurulması, ortadan kaldırılması, birleştirilmesi, adının ve sınırlarının değiştirilmesi gibi durumlarda ilk karar (görüşme) merciinin belediye meclisinin olmasi,

- Organlarının (muhtar ve ihtiyar heyeti üyeleri) seçilmesiyle ilgili hususların merkezi idareye bağlı seçilmişlerle (Cumhurbaşkanı, Milletvekili) değil yerel yönetimlerin seçilmişleriyle (İl Genel Meclisi Üyesi, Belediye Başkanı, Belediye Meclis Üyesi, Köy Muhtarı, Köy İhtiyar Meclisi Üyesi) birlikte düzenlenmesi,

- Belediye sınırları içerisinde kurulan bir kentsel (yerel) yönetim mekanizması olarak görülmesi,

- Karar organlarının seçimle işbaşına gelmesi,

- Sinırlı düzeyde olsa da belirli bir özerkliğinin bulunması, 
- Kaymakamlık vd. merkezi idare birimlerine organik (teşkilatsal) bir bağlarının bulunmaması,

- Kaymakamlıklardan daha alt düzeydeki merkezi idare birimlerinden uzaklaşma politikasının bulunması dolayısıyla bucaklardan bile daha küçük ölçekli bir merkezi idare biriminin varlığının düşünülememesi,

- En küçük ve yerel düzeydeki mahalli idare olan köy muhtarlıklarının büyükşehir belediyeleri içerisinde mahallelere dönüştürülmüş olmasi,

- Gider ve ihtiyaçlarının belediyelerce karşılanması.

Mahalle muhtarlıklarının genel tanımı 5393 sayılı Belediye Kanunu'nda (md.3/d) yapılmıştır. Bununla birlikte belediye sınırları içinde mahalle kurulması, kaldırılması, birleştirilmesi, bölünmesi, adlarıyla sınırlarının tespiti ve değiştirilmesindeki usul, süreç ve şartlar ile mahalle yönetimlerinin temel organları, muhtarın genel olarak görevleri, kentsel hizmetlerde belediye - mahalle uyumluluğu, mahalle muhtarlığının gider ve ihtiyaçlarının karşılanması gibi hususlarda aynı kanunun 9'uncu maddesinde ortaya konmuştur. Dolayısıyla mahalleler ile ilgili en genel ve temel düzenlemeler belediye kanununda yapılmıştır. Bununla birlikte şehir ve kasabalarda yani belediye sınırları içerisinde mahalle kurulması ile mahalle muhtarı ve ihtiyar heyetinin görevleri 1944 tarih ve 4541 sayılı kanunda daha detaylı bir şekilde düzenlenmiştir. 5442 sayılı "İl İdaresi Kanunu" içeriğinde ise mahallelerle ilgili herhangi bir düzenleme yapılmamıştır. Buradan hareketle her ne kadar mahalle yönetimleri tüzel kişiliğe haiz ayrı bir yerel yönetim birimi olarak kurgulanmasa da 1940'lı yıllardan bu yana merkezi idare içerisinde ilişkilendirilmediği de oldukça açıtır. Ayrıca mahallelerin kurulması, ortadan kaldırılması, birleştirilmesi, adının ve sınırlarının değiştirilmesi gibi durumlarda ilk karar merciinin il/ilçe idare kurulları yerine belediye meclisinin olması da tesadüfi olarak düşünülemez.

Mahalle yönetimlerinin organları yerel idarelerde olduğu gibi seçimle işbaşına gelmektedir. Bu seçimler de merkezi idareye ait genel seçimler içerisinde olmayıp, mahalli idareler içerisinde gerçekleştirilmektedir. Ayrıca mahalle organlarının seçilmesiyle ilgili usul ve esasların merkezi idareye bağlı seçilmişlerle birlikte düzenlenmesi yerine, yerel yönetimlerin seçilmişleriyle birlikte 2972 sayılı kanunla düzenlenmesi de bu konuda destekleyici bir çıkarımdır.

Mahalle muhtarlıkları 5393 sayılı Belediye Kanunu'nun 9'uncu maddesinde yer alan "...muhtar, mahalle sakinlerinin gönüllü katılımıyla ortak ihtiyaçları belirlemek, mahallenin yaşam kalitesini geliştirmek, belediye ve diğer kamu 
kurum ve kuruluşlarıyla ilişkilerini yürütmek, mahalle ile ilgili konularda görüş bildirmek, diğer kurumlarla iş birliği yapmak ve...", hükmü gereğince, belediye sinırları içerisinde kurulan ve en yerel nitelikteki (mahalle düzeyindeki) ortak ihtiyaçların belirlenmesi, bu ihtiyaçların giderilmesiyle ilgili diğer kamu kurumlarıyla/idareleriyle iş birliğinin sağlanması ve yerel nitelikteki bu ortak ihtiyaçların giderilmesindeki yaşam kalitesinin geliştirilmesinde görev yapan bir idari birim olarak değerlendirilmektedir. Dolayısıyla mahallenin bu görev ve fonksiyonları merkezi idarenin görev ve sorumluluklarından daha ziyade yerel idarelerin varlık sebepleri yani görev ve sorumluluklarıyla ilgilidir.

\section{Mahalle Yönetimlerinin Kurulması/Kaldırılması ve Organik Yapısı}

5393 sayılı Belediye Kanunu (md.9) hükmü gereğince belediye sınırları içinde mahalle kurulması, kaldırılması, birleştirilmesi, bölünmesi, adlarıyla sınırlarının tespiti ve değiştirilmesi belediye meclisinin kararı ve kaymakamın görüşü üzerine valinin onayı ile yapılmaktadır. Aynı madde hükmü gereğince de belediye sınırları içinde nüfusu 500'ün altında mahalle kurulamaz.

Mahalle; muhtar ve ihtiyar heyeti tarafından yönetilir. Kurulacak olan mahallelerde bir muhtar ve muhtarın başkanlığında bir ihtiyar heyeti bulunur. Yapılacak işler bakımından bir kaç mahallenin bir muhtar ve ihtiyar heyetine bağlanması veya bir mahallede birden fazla muhtar ve ihtiyar heyeti bulunması belediye meclisinin kararına ve o mahallin en büyük mülki amirinin onayına bağlıdır. Mahalle ihtiyar heyeti, muhtar ile dört azadan oluşmaktadır. Heyetin dört yedek azası da bulunmaktadır (4541/md.1-2).

Mahalle muhtarı ve ihtiyar heyeti üyelerinin seçilmesiyle ilgili usul ve esaslar 1984 tarih ve 2972 sayılı "Mahalli İdareler İle Mahalle Muhtarlikları ve İhtiyar Heyetleri Seçimi Hakkında Kanun"da düzenlenmiştir. Buna göre Mahalli İdareler seçimleri beş yılda bir yapılmaktadır. Her seçim döneminin beşinci yılındaki 1 Ocak günü seçimin başlangıç tarihidir. Aynı yılın Mart ayının son Pazar günü ise oy verme günüdür. Milletvekili Seçimi Kanununun 7'nci maddesinin son fikrası gereğince yapılan seçimler hariç, milletvekili genel veya ara seçiminden önceki veya sonraki bir yıl içinde yapılması gereken mahalli idareler organlarına veya bu organların üyeliklerine ilişkin genel veya ara seçimler, milletvekili genel veya ara seçimleri ile birleştirilir. Mahalli idareler seçiminin savaş hali nedeniyle bir yıla kadar ertelenmesi yasayla düzenlenir (md.8). Muhtarlar mahalli idareler seçim- 
lerinde adaylıklarını koyabilmek veya aday gösterilebilmek için görevlerinden istifa etmek zorunda değildirler. Milletvekilliği, belediye başkanl1$\breve{g}$, il genel meclisi ve belediye meclisi üyeliği ile muhtarlık bir şahıs uhdesinde birleşemez. Bu görevlerin birisinde bulunanlardan bir diğerine seçilenler, seçim sonuçlarının kendilerine tebliğ edildiği tarihten itibaren 15 gün içinde tercih haklarını kullanırlar. Bu süre içinde tercih haklarını kullanmayanlar seçildikleri yeni görevi reddetmiş sayılırlar (md.17). Mahalle ihtiyar heyetine sekiz üye seçilir. Oyların tasnifi sonucunda en çok oy alan dört üye asıl, geri kalanlar ise yedek üye olur (md.30/b). Muhtarlık ve ihtiyar heyeti üyeliği seçimlerinde adaylık usulü bulunmamaktadır. En az altı aydır aday konulan mahallede oturmak şartıyla, 18 yaşını dolduran her Türk vatandaşı, kanunlarda öngörülen hükümlerce seçilmeye mani hali olmamak kaydıyla muhtar ve ihtiyar heyeti üyesi seçilebilir. Bu kişiler için herhangi bir mezuniyet şartı aranmamaktadır. Muhtarlık ve ihtiyar heyeti üyeliği için okur-yazar olmak yeterlidir (md.31). Mahalle muhtarlığının herhangi bir nedenle boşalması durumunda ihtiyar heyetinin 1. üyesi mevcut hali yazılı olarak ilgili seçim kurulu ve mahallin en büyük mülki idare amirine bildirmesi zorunludur. Boşalmış muhtarlıkların seçimi her yılın haziran ayının ilk pazar günü yapılır. Seçim yapılına kadar muhtarlık görevini mahallin en büyük mülki amiri tarafından atanan muhtar vekili yerine getirir. Seçim döneminin bitmesinden önce ihtiyar heyeti üye say1sinın yedeklerinin de getirilmesinin ardından üye tamsayısının yarısına kadar düşmüş olması durumunda muhtar, durumu bir hafta içerisinde ilgili olan seçim kurulu başkanlığına ve bilgi amacıyla da mahallin en büyük mülki amirine bildirir. Bu bildirim sonrası ilçe seçim kurulu başkanlığ1 tarafından durum 48 saat içerisinde ilan edilir. İlan tarihinden itibaren altmışıncı günü takip eden ilk pazar günü oy kullanılır. İhtiyar heyeti seçiminin yapılmasına ihtiyaç duyulması halinde mahalle muhtarlı̆̆ının da boşalmışsa haziran ayı beklenmeden her iki seçim birlikte yapılır (md.33).

Mahalle muhtarı ve ihtiyar heyetinin görev ve sorumlulukları 4541 sayılı Şehir ve Kasabalarda Mahalle Muhtar ve İhtiyar Heyetleri Teşkiline Dair Kanunda (md.3) ayrıntılı olarak belirtilmiştir. Ancak ilgili kanunda belirlenen birçok madde günümüzde etkinliğini (uygulamasını) kaybetmiştir. Hatta görevin kaynağı olarak atıfta bulunan ilgili kanunların birçoğu yürürlükten kaldırılmış ya da içeriği büyük ölçüde değiştirilmiştir. Ancak ilgili güncellemeler (mülga edilme, değiştirilme, vd.) kanun koyucu tarafından tarihsel süreçte maalesef 4541 sayılı yasa üzerinde gerçekleştirilmemiştir. Ancak halen yürürlükte olması nedeniyle ilgili kanunda belirtilen görev ve sorumluluklar aşağıdaki tabloda gösterilmiştir. 
Tablo 1. Mahalle Muhtarının ve İhtiyar Heyetinin Görevleri ve Yasal Dayanakları

\begin{tabular}{|c|c|c|}
\hline Görevin Adı & $\begin{array}{c}\text { Görevin Muhata- } \\
\text { b1/Sorumlusu }\end{array}$ & $\begin{array}{c}\text { Hukuki } \\
\text { Dayanak }\end{array}$ \\
\hline $\begin{array}{l}\text { Kendilerini nüfus sicillerine kaydettirmemiş olanlara } \\
\text { nüfus ilmühaberi vermek. Askerlik yoklama memurları } \\
\text { tarafından istenilen bilgileri vermek, Askerlik şubelerine } \\
\text { davet pusulalarını imza karşılığında teslim alarak sahip- } \\
\text { lerine tebliğ etmek. Askere sevk cetvellerini ilgililerine } \\
\text { tebliğ etmek ya da teslim edilmeyenleri ilgili mercilere } \\
\text { bildirmek, Askere sevk tarihinden itibaren akıbeti meç- } \\
\text { hul olanlar hakkında durum belgesi vermek. }\end{array}$ & $\begin{array}{l}\text { Muhtar } \\
\text { Başkanlığında } \\
\text { İhtiyar Heyeti } \\
\text { (oy çokluğuyla) }\end{array}$ & $\begin{array}{c}4541 \text { sayılı } \\
\text { yasa }\end{array}$ \\
\hline $\begin{array}{l}\text { Doğum vakalarını nüfus idarelerine bildirmekle mükel- } \\
\text { lef olanlara ilmühaber vermek, Ölüm vakaları için nüfus } \\
\text { dairelerine ilmühaber vermek. }\end{array}$ & $\begin{array}{l}\text { Muhtar } \\
\text { (2 şahit huzurunda) }\end{array}$ & $\begin{array}{c}4541 \text { sayılı } \\
\text { yasa }\end{array}$ \\
\hline $\begin{array}{l}\text { Hüviyet (kimlik) cüzdanını kaybedenlere nüfus ilmüha- } \\
\text { beri vermek. Yer değiştirmelerinin kütüklere kaydı için } \\
\text { ilgililerine ilmühaber vermek, Sanat, sıfat, mezhep ve } \\
\text { eşkâl gibi hususların nüfus sicillerine kaydı için talep } \\
\text { edenlere ilmühaber vermek Askerlik çağında olanlardan } \\
15 \text { günden fazla bir süre şubesinin bulunduğu idari } \\
\text { birimden dışarı çıkmak isteyenleri askerlik şubelerine } \\
\text { bildirmek. } \\
\text { Veraset ve İntikal Vergisi Kanunu hükümlerine göre: } \\
\text { mahallede her geçen ay içindeki ölüm vakalarını ertesi } \\
\text { ayın on beşine kadar varidat (vergi) dairelerine yazı ile } \\
\text { bildirmek. }\end{array}$ & Muhtar (tek başına) & $\begin{array}{c}4541 \text { sayılı } \\
\text { yasa }\end{array}$ \\
\hline
\end{tabular}

1525 numaralı Şose ve Köprüler Kanunu hükümlerine göre yol vergisi ile mükellef olanlar için hususi muhasebelerden verilecek cetvelleri doldurmak.

Hukuk Usulü Muhakemeleri Kanun (HUMK)'a göre Sulh hakimleri nezdinde görülecek davalara ait vekaletname imzaların onaylamak, imza atamayan veya okuma yazması olmayanların kullanacağı mühür ya da el ile yapacağı işareti tasdik etmek.

Muhtar

$\begin{array}{lc}\text { Başkanlığında } & 4541 \text { sayılı } \\ \text { İhtiyar Heyeti } & \text { yasa }\end{array}$

(oy çokluğuyla)
Adli müzaheret (yardım) talebinde bulunanların mahkemeye ibraz edecekleri durum belgelerini tanzim etmek.

\begin{tabular}{|c|c|c|}
\hline $\begin{array}{l}\text { Ceza Muhakemeleri Usul Kanun (CMUK)'a göre bir } \\
\text { davayı temyiz talebinde bulunacakların yatırmak zo- } \\
\text { runda oldukları depo şartından istisna tutulabilmesi için } \\
\text { ilgililerine yoksul olduklarına dair ilmühaber vermek. }\end{array}$ & $\begin{array}{l}\text { Muhtar } \\
\text { Başkanlığında } \\
\text { İhtiyar Heyeti } \\
\text { (oy çokluğuyla) }\end{array}$ & $\begin{array}{l}4541 \text { sayilı } \\
\text { yasa }\end{array}$ \\
\hline $\begin{array}{l}\text { CMUK'a göre zabıtaca yapılacak bina aramalarında } \\
\text { hazır bulunmak. }\end{array}$ & $\begin{array}{l}2 \text { aza } \\
\text { tarafından yapilır }\end{array}$ & $\begin{array}{l}4541 \text { sayil1 } \\
\text { yasa }\end{array}$ \\
\hline $\begin{array}{l}\text { İcra Kanunu hükümlerine göre yapılacak hacizlerde } \\
\text { hazır bulunmak ve borçlarını ödemeyenlerin mali (öde- } \\
\text { me) gücü olup olmadığına dair ilmühaber (belge) ver- } \\
\text { mek. Zararlı hayvanların itlafı hakkındaki kanun hük- } \\
\text { müne göre hayvanların öldürülmesi için kullanılacak } \\
\text { silah ve eşyaları mücadele mevsiminde mücadele heye- } \\
\text { tinden makbuz karşıllğında alarak tevzi etmek ve mev- } \\
\text { sim sonunda silahları ve kullanılmamış maddeleri top- }\end{array}$ & $\begin{array}{l}\text { Muhtar } \\
\text { Başkanlığında } \\
\text { İhtiyar Heyeti } \\
\text { (oy çokluğuyla) }\end{array}$ & $\begin{array}{l}4541 \text { sayilı } \\
\text { yasa }\end{array}$ \\
\hline
\end{tabular}




\begin{tabular}{|c|c|c|}
\hline layarak heyete teslim etmek. & & \\
\hline $\begin{array}{l}\text { Her yıl okul açlmadan on beş gün evvel semtin bağlı } \\
\text { bulunduğu ilkokulun başöğretmeni (müdürü) ile birlikte } \\
\text { mahalle hududu içinde oturan ve mecburi Öğrenim } \\
\text { yaşında olan çocukların bir cetvelini tanzim ederek } \\
\text { (listesini hazırlayarak) mühürlemek ve bu cetvelde } \\
\text { (listede) adları yazıllı çocuklardan okula devama mecbur } \\
\text { olanları bu müddet içinde velilerine bildirmek ve de- } \\
\text { vamsızlıkla ilgili her türlü tebliğ ve takiplere tavassut } \\
\text { (aracllı) etmek. }\end{array}$ & $\begin{array}{l}\text { Muhtar } \\
\text { Başkanlı̆̆ında } \\
\text { İhtiyar Heyeti } \\
\text { (oy çokluğuyla) }\end{array}$ & $\begin{array}{l}4541 \text { sayilı } \\
\text { yasa }\end{array}$ \\
\hline $\begin{array}{l}2644 \text { numaralı Tapu Kanunu hükümlerine göre: Ferağ } \\
\text { ve intikal ve kayıt işlerine ait ilmühaber ve vesikalar } \\
\text { vermek ve meskenlere girerken hazır bulunmak. }\end{array}$ & $\begin{array}{l}\text { Muhtar Başkanlığın- } \\
\text { da İhtiyar Heyeti } \\
\text { (oy çokluğuyla) }\end{array}$ & $\begin{array}{l}4541 \text { sayil1 } \\
\text { yasa }\end{array}$ \\
\hline $\begin{array}{l}\text { Mahalleye girdiğini haber aldığı hüviyeti meçhul ve } \\
\text { şüpheli şahıslar hakkında zabıtaya haber vermek. } \\
\text { İnsan ve hayvanlara arız olan salgın ve bulaşıı hastalık- } \\
\text { ların ve nebatata hasar veren haşerelerin zuhurunu } \\
\text { (varlığını) haber aldığı gün Hükümete (ilgili kurumlara) } \\
\text { bildirmek }\end{array}$ & Muhtar (tek başına) & $\begin{array}{l}4541 \text { sayilı } \\
\text { yasa }\end{array}$ \\
\hline $\begin{array}{l}\text { Yardıma muhtaç olanlara fakirlik ihtiyaç ilmühaberleri } \\
\text { vermek, Mahallede sakin olanlar (ikamet edenler) hak- } \\
\text { kında resmi müesseselerce istenilen hüsnühal (iyihal/iyi } \\
\text { durum) varakalarını (belgeleri) tanzim ve ikametgah } \\
\text { senedi tasdik etmek. }\end{array}$ & $\begin{array}{l}\text { Muhtar Başkanlığın- } \\
\text { da İhtiyar Heyeti } \\
\text { (oy çokluğuyla) }\end{array}$ & $\begin{array}{l}4541 \text { sayilı } \\
\text { yasa }\end{array}$ \\
\hline $\begin{array}{l}\text { Cumhurbaşkanınca halkın ihtiyaçlarını karşılamak ve } \\
\text { kamu hizmetlerini kolaylaştırmak üzere alınan kararları } \\
\text { mahalle düzeyinde uygulamak. }\end{array}$ & $\begin{array}{l}\text { Muhtar ve } \\
\text { İhtiyar Heyeti }\end{array}$ & $\begin{array}{l}4541 \text { sayil1 } \\
\text { yasa }\end{array}$ \\
\hline $\begin{array}{l}\text { Mahalle sakinlerinin gönüllü katılımıyla mahallenin } \\
\text { ortak ihtiyaçları belirlemek, mahallenin yaşam kalitesini } \\
\text { geliştirmek. Mahalle adına belediye ve diğer kamu } \\
\text { kurum ve kuruluşlarıyla ilişkileri yürütmek, Mahalle ile } \\
\text { ilgili konularda (ilgili idare ve kurumlara) görüş bildir- } \\
\text { mek. }\end{array}$ & Muhtar (tek başına) & $\begin{array}{r}5393 \text { sayllı } \\
\text { yasa (md.9) }\end{array}$ \\
\hline Kanunlarla verilen diğer görevleri yapmak & $\begin{array}{l}\text { Muhtar } \\
\text { (genellikle tek başına) }\end{array}$ & $\begin{array}{r}5393 \text { sayll1 } \\
\text { yasa (md.9) }\end{array}$ \\
\hline $\begin{array}{l}\text { Mahalle muhtarları oy hakkı olmaksızın kendi görev ve } \\
\text { faaliyet alanlarına giren konuların görüsülddüğü ihtisas } \\
\text { komisyonu toplantılarına katılabilir ve görüş bildirebilir }\end{array}$ & Muhtar (tek başına) & $\begin{array}{c}5393 \text { sayıl1 } \\
\text { yasa } \\
\text { (md.24) }\end{array}$ \\
\hline $\begin{array}{l}\text { Kent konseyi üyesi olmaları dolayısıyla konseyin toplan- } \\
\text { tı ve faaliyetlerine katılırlar }\end{array}$ & Muhtar (tek başına) & $\begin{array}{c}5393 \text { sayll } \\
\text { yasa } \\
(\text { md.76) }\end{array}$ \\
\hline $\begin{array}{l}\text { Muhtarlar her türlü seçim işleri ve seçmen kütükleri } \\
\text { yazımında, seçim kurullarının istediği bilgileri ve belge- } \\
\text { leri gecikmeden, süresinde ve doğru olarak göndermek } \\
\text { zorundadırlar }\end{array}$ & Muhtar (tek başına) & $\begin{array}{c}298 \text { sayılı } \\
\text { yasa (md.9) }\end{array}$ \\
\hline $\begin{array}{l}\text { Muhtarlar, muhtarlık bölgesi askı listesini, seçim dönem- } \\
\text { lerinde muhtarlıklarda askıya çıarmakla da sorumlu- } \\
\text { durlar }\end{array}$ & Muhtar (tek başına) & $\begin{array}{c}298 \text { sayilı } \\
\text { yasa } \\
\text { (md.40) }\end{array}$ \\
\hline $\begin{array}{l}\text { Muhtarlar, oy verme gününden } 10 \text { gün önceden oy } \\
\text { verme günü saat } 17.00^{\prime} \text { ye kadar; çalışma saatleri içinde } \\
\text { seçmenlerin sandık numarası, sandık yeri ve oy verme }\end{array}$ & Muhtar (tek başına) & $\begin{array}{c}298 \text { sayıl1 } \\
\text { yasa } \\
\text { (md.43) }\end{array}$ \\
\hline
\end{tabular}




\begin{tabular}{|c|c|c|}
\hline $\begin{array}{l}\text { hakkındaki sualleri cevaplandırmak, seçim kurullarının } \\
\text { yayınlarını dağıtmak, seçim kurullarının vatandaşın } \\
\text { kolay ve doğru oy vermesi için hazırlayacağı afiş, işaret, } \\
\text { levha ve benzerlerini asmak ve dağıtmak, bu işlem için } \\
\text { seçim kurulu ayrıca personel görevlendirirse, bu perso- } \\
\text { nele yardımcı olmak zorundadırlar. }\end{array}$ & & \\
\hline $\begin{array}{l}\text { Tebligat kanununa göre, kendisine tebligat yapılacak } \\
\text { kişinin ilgili adreste bulunamaması durumunda muhta- } \\
\text { rın ilgili evrakı tebellüğ etme yükümlüğü bulunmakta- } \\
\text { dır. }\end{array}$ & $\begin{array}{l}\text { Muhtar (tek başına) } \\
\text { ya da ihtiyar heyeti } \\
\text { üyesinden birisi }\end{array}$ & $\begin{array}{l}7201 \text { sayil1 } \\
\text { yasa } \\
(\mathrm{md} .21)\end{array}$ \\
\hline $\begin{array}{l}\text { Kadastro kanunu uyarınca, kadastro ekibine katılmak ve } \\
\text { kadastro çalışması sonrasında kadastro ilanlarını askıya } \\
\text { çıarmak }\end{array}$ & Muhtar (tek başına) & $\begin{array}{l}3402 \text { sayıl1 } \\
\text { yasa (md.3 } \\
\text { ve } \text { md.11) }\end{array}$ \\
\hline $\begin{array}{l}213 \text { sayılı Vergi Usul Kanunu kapsaminda takdir komis- } \\
\text { yonu toplantılarına katılmak }\end{array}$ & Muhtar (tek başına) & $\begin{array}{c}213 \text { sayilı } \\
\text { yasa } \\
\text { (md.72) }\end{array}$ \\
\hline $\begin{array}{l}\text { Mahalle sinırları içerisinde meydana gelen ölüm ve } \\
\text { veraset intikallerini ertesi ayın 15'ine kadar ilgili vergi } \\
\text { dairesi müdürlüğ̈üne bildirmek }\end{array}$ & Muhtar (tek başına) & $\begin{array}{c}213 \text { sayilı } \\
\text { yasa } \\
\text { (md.150) } \\
\end{array}$ \\
\hline $\begin{array}{l}\text { Gelir vergisi indiriminden faydalanmak isteyenlere, } \\
\text { başvuru olması halinde, ihtiyaç duyulan hüviyet (kim- } \\
\text { lik) tasdiki işlemini yapmak }\end{array}$ & Muhtar (tek başına) & $\begin{array}{c}213 \text { sayilı } \\
\text { yasa } \\
(\mathrm{md} .249)\end{array}$ \\
\hline
\end{tabular}

Kaynak: Yazarlar tarafından muhtelif mevzuat hükümleri taranarak oluşturulmuştur.

5393 sayılı Belediye Kanunu'nda (md.9) mahalle ile ilgili görevler genel olarak belirtilmiş olup; bu görevlerin muhtar tarafından yerine getirilmesi ve bu kapsamda zorlama olmadan mahalle halkının da gönüllü katılımının söz konusu olacağı/olabileceği hüküm altına alınmıştır. Yine kanun metnindeki "..kanunla verilen diğer görevleri yapmak" ibaresi de 5393 ve diğer kanunlarla belirtilen görev ve sorumlulukların yerine getirilmesiyle ilgili depo niteliğinde bir hükümdür.

4541 sayılı yasada tanımlanan görevler genel olarak merkezi idarenin taşra birimleri tarafından yerine getirilmekte olan kamu hizmetlerine mahalle düzeyinde yardımcı olunmasını öngören bir formattadır. Daha yalın bir ifadeyle mahalle muhtarları/muhtarlıkları merkezi idarenin kamu hizmetleri sunumunda kendilerine yardımc olan bir alt birim olduğu yönünde bir intiba bırakmaktadır. Ancak 5393 sayılı yasa ile bu intiba önemli ölçüde ortadan kalkmıştır. Özellikle kanunun muhtarları, yönettikleri mahallelerin "yerel temsilcisi" statüsüne koymaları bu anlamda büyük bir önem taşımaktadır. Nitekim 5393 sayılı yasaya kadar mahalle muhtarlarının bulundukları mahalle halkını temsil etme gibi hukuki bir misyonu bulunmamaktaydı. Muhtarların mahalle ile ilgili konularda belediye ihtisas meclislerinde bilgi ve görüş bildirmeleri; kent konseylerinin mahalle düzeyindeki üyelerinden olması; mahallelerin (en yerel düzeyde) ihtiyaç- 
ları, sorunları ve geleceği hakkında diğer kamu idare, kurum ve kuruluşları önünde mahalleyi temsilen bilgi, görüş, değerlendirme, beyan ve oy vermesi mevcut kanaatin önemli ölçüde ortadan kalkmasına katkı sağlamaktadır. Ancak mevcut genel durum halen mahalle muhtarliklarının hukuki durumları üzerindeki tartışmayı çözecek açıklıkta olmadığı da bilinen bir gerçektir.

\section{Mahalle Muhtarı ve İhtiyar Heyeti Üyelerinin Özlük Hakları ile İdari/Cezai Sorumlulukları}

Mahalle muhtarlıklarının tüzel kişiliğinin bulunmaması, ayrı (bağımsız) bir bütçeye sahip olmalarının önünde büyük bir engeldir. Ayrı bir bütçeleri olmadığı için icrai nitelikte kamusal hizmetler gerçekleştirememektedirler. İstisnai olarak 4541 sayılı yasa ile gerçekleştirdikleri bazı hizmetler karşılığında hizmet harcı alma hakkı tanınmıştır. Ancak bu harçlardan kişisel gelir elde edemezler. Başka bir ifadeyle bu harçları ancak muhtarlık gideri olarak kullanabilirler. Mahalle muhtarları, 1977 tarih ve 2108 sayılı Muhtar Ödenek ve Sosyal Güvenlik Yasası kapsamında aylık ödenek alırlar. Yasaya göre bu ödenek her yıl İçişleri Bakanlığı bütçesine konulur ve ilgili yıl içinde söz konusu bütçeden il özel idare bütçelerine aktarılır (md.1/3). Daha önceden ilişkili oldukları sosyal güvenlik kapsamından da primlerinin yatırılması devam eder. Herhangi bir sosyal güvencesi bulunmayanlar ise sosyal güvenlikle ilişkilendirilirler. Ancak bu güvencenin muhtarlık sonunda devam edebilmesi için muhtarların kanuni primlerini kendilerinin ödemeleri gerekmektedir. Mahalle muhtarların izin hakkı, silah taşıma hakkı ve istifa etme hakları da bulunmaktadır. Bu haklar genellikle genel hükümler çerçevesinde ele alınmaktadır. Örneğin muhtarların izin hakkı bulunmasına rağmen, bu hakkın süresi ile ilgili bir düzenleme bulunmamaktadır. Bu süre diğer kamu görevlileri de dikkate alınarak bir ayı geçemez demektedir. Ancak kamu hukukunda kıyas ilkesinin sınırlı olması da dikkate alınarak bu yaklaşım hukuki olarak bir kesinlik oluşturmaz ve her zaman da kabul görmeyebilir (Aytaç, 2004, s.152-158).

2018 yılında mahalle muhtarları için başta aylık ödenek ve SGK primlerinin devlet tarafından ödenmesi olmak üzere bazı özlük haklarına ilişkin sınırlı olarak hukuki düzenlemeler yapılmış olmasına karşın, ihtiyar heyeti üyeleri konusunda herhangi bir düzenlemenin yapılmadığı görülmektedir. Türkiye'de ihtiyar heyeti üyeleri tamamen gönüllülük esasına göre ve sinırlı bir yetkiyle görevlerini ifa etmektedirler. 
Mahalle muhtarları devlet memuru değildirler. Ancak seçilmişler görev ve sorumluluklarıyla ilgili olarak kamu hukuku hükümlerine tabi oldukları için "geniş anlamda kamu görevlisi" sayılmaktadırlar (Mecek ve Doğan, 2015, s.215). Dolayısıyla mahalle muhtarları ve ihtiyar meclisi üyeleri görev, yetki ve sorumluluklarıyla ilgili soruşturma ve kovuşturmalarda 4483 sayılı yasa hükümlerine tabidirler. Dolayısıyla kamu görevlisi sayılmaları nedeniyle görevleriyle ilgili olarak alelade bir vatandaş gibi soruşturulamaz ya da kovuşturulamaz. Ancak ceza almaları halinde de kamu görevlisi sayıldıkları için genellikle alelade bir vatandaşa göre aynı fiilden daha fazla ceza almaktadırlar.

4541 sayılı yasa kapsamında (md.18) mahalle muhtarlarının ve ihtiyar meclisi üyelerinin görevlerini ifa etmemeleri ya da geciktirmeleri durumunda mahallin en büyük mülki amiri olan kaymakam ya da valilerce yazılı uyarıya maruz kalmaları söz konusudur. Yazılı uyarıya rağmen mevcut durumun değişmemesi halinde aynı makamlarca görevden el çektirme ya da görevin sona erdirilmesi cezaları uygulanabilmektedir. İlgililerince bu kararlara karşı idari yargıda iptal davası açılabilir. Belediye ve il özel idarelerinde ise seçilmişlerin görevine son verilebilmesi için son karar mülki idare amirlerinde değil, yargı organlarındadır. Ölüm, istifa, mahkûmiyet ve seçilme yeterliliğinin ortadan kalkması gibi sebeplerle de muhtarlık ve ihtiyar meclisi üyeliği görevleri sona ermektedir.

\section{Sonuç}

Kentsel alan yönetiminin temel yapı taşı olan mahallelerin etkin ve verimli bir şekilde varlığını devam ettirebilmesi için optimal bir mevzuat alt yapısına, ideal bir organizasyona, etkin organlara, personele ve mali kaynaklara ihtiyaç duyulmaktadır. Bu haliyle ihtiyaç duyulan tüm bu bileşenlerin en ideal bir kombinasyon ile bir araya getirilmesi gerekmektedir. Çalışmamız ile mahalle muhtarlıklarının şu anki mevcut durumuna ışık tutulmaya çalışılmıştır. Ancak asıl gaye bu konuda yapılacak yeni mevzuat çalışmaları için katkılar sağlamaktır.

Mahalle muhtarlıklarının tüzel kişiliğinin olmaması, etkinliği önündeki en önemli engeldir. Çünkü kendilerine ait mali imkânları ve personel istihdamı olanakları bulunmamaktadır. Ayrıca protokol, sözleşeme vb. hukuki işlemleri de gerçekleştirememektedirler. Mahalle muhtarlıklarının sahip olduğu tüm yetkilerin zaman içerisinde belediyelere ve özellikle merkezi idarenin taşra birimlerine aktarılmış 
olması sadece etkinliklerini ortadan kaldırmamış, varlıklarını da sorgulanır hale getirmiştir. Çünkü mahalle muhtarları günümüzdeki formuyla tebligat işlemlerine yardımcı olan bir kamu görevlisi ve sosyal yardımlarda mahalle halkını tanıyan bir aracı kişi olma konumu içerisine hapsedilmiştir. Her ne kadar mahalli düzeyde halkın siyasal mobilizasyonunu, katılım ve demokrasi kültürünü arttırıcı bir etkiye sahip olsa da kamu hizmeti sunumu noktasında oldukça pasif bir hale getirilmiştir. Bu sebeple mahalle muhtarlığı biriminin ve unsuru olan muhtarların hukuku statüsü, görev, yetki ve sorumlulukları ile diğer kamu kurum ve idarelerle olan hukuki ilişkisi bir bütün olarak yeniden ele alınmalıdır. Belediye, il özel idaresi ve köy de olduğu gibi mahallelerin de kendine özgü ayrı bir kanunla yeniden düzenlenmelidir. Bu durum mahalle muhtarlıkları ile ilgili aşırı parçalı ve sı̆̆ olan mevzuat hükümlerini daha derli toplu ve sistematik hale getirecektir.

Türkiye'de 2012 yılında yapılan değişiklikler ile özellikle büyükşehir olan illerdeki yönetim birimleri ile ilgili köklü değişiklikler yapılmıştır. 2019 yılında yapılan yerel seçimler sonrasında da merkezi hükümet yetkilileri ve siyasi ortakları tarafından da yeni düzenleme önerileri kamuoyu ile paylaşılmıştır. Dolayısıyla büyükşehir belediyesi, ilçe belediyeleri ve mahalle yönetimleri başta olmak üzere tüm yönetsel unsurları etkileyecek bu gelişmeleri mahalle odağında birkaç örnek modelde bütünleştirmek yararlı olacaktır. Bu sayede yeni yapılacak olası hukuki düzenlemelere alternatifler sunulmuş olacaktır.

Türkiye'de mahalle muhtarlıkları ile ilgili çok fazla model geliştirilebilir. Ancak yaşanan siyasal gelişmeler ve beklentilerden yola çıkarak birkaç tane ile sınırlı kalınması tercih edilecektir. Bu kapsamda;

- Birinci Model: Mahalle muhtarlıklarına tüzel kişilik verilmesi ve yetkilerinin arttırılmasıdır. Muhtarlıklar tüzel kişiliğe sahip olacakları için kendilerine ait bütçeleri ve harcama yapabilme olanakları olacaktır. Yine uzman personel istihdam etme, hizmet alımı yapma, vd. imkanlara kavuşacaklardır. Hatta mahalle ölçeğindeki siyasal katılım ve demokrasi kültürünün gelişmesine çok daha fazla katkı sağlanacaktır. Hesap sorulabilirlik te arttırılabilecektir. Ancak belediye sınırları içerisinde birden çok alt tüzel kişiliklerin olması belediye ile mahalle muhtarlıkları arasında görüş farklılıklarına dayalı krizlerin yaşan- 
masına neden olunabilir. Yine mahalleler arasında hizmet sunumunda farklılıkların yaşanması, kent içi eşitsizliklerin ortaya çıkmasına sebebiyet verebilir. Yine belediyelerin hesap verebilirlik noktasında sorumluluklarını mahalle muhtarlıklarına yükleme imkânı ortaya çıkabilir.

- İkinci Model: Tüzel kişiliği olmayan mahalle muhtarlıklarını tamamen ortadan kaldırmak ve belediyeler içerisinde organik anlamda belediyelerin bir alt birimi haline dönüştürmektir. $\mathrm{Bu}$ durumda mahalle muhtarları seçilen belediye başkanı ya da seçilen belediye meclisi tarafından doğrudan doğruya mahalle düzeyinde atanacaktır. Belediye tarafından kendisine yer, araç, personel ve mali kaynaklar aktarılan muhtarlıklar, belediye başkanı, meclis ve encümen ile çok daha koordineli ve etkin çalışacaktır. İki seçilmiş organın karşı karşıya gelmesi yerine seçilmiş bir organ tarafından atama yolu ile göreve getirilmiş bir idari alt birim mevcut olacaktır. İki birim arasında siyasi çekişme, fikir ayrılığı, uyumsuzluk gibi sorunlar yaşanmayacaktır. Bununla birlikte belediyenin kaynaklarının mahalle üzerindeki kullanımı noktasında çok daha etkin bir sistem inşa edilmiş olacaktır. Bu durumda mahalle düzeyinde bir seçim atmosferi olmayacağı için görünüşte siyasal mobilizasyon, katılım ve demokrasi kültürünün geliştirilmesinde olumsuz bir durum ortaya çıkacaktır. Ancak eğitim durumu, tecrübe vb. birçok hususta daha olumlu özelliklere sahip yeni yöneticiler ortaya çıkacaktır. Kaldı ki siyasal partiler bu durumda mahalle düzeyinde teşkilatlanmaya gidecekleri için mahalle kültürü içerisinde siyaset, siyasal katılım gibi unsurların var olduğu kültürün gelişmesine de önemli katkılar sunulacaktır.

- Üçüncü Model: Mahalle muhtarlıklarının kent konseyleri içerisinde ayrı bir çalışma meclisi ya da grubu haline dönüştürülmesidir. Bu durumda da mahalle muhtarlıkları yine tamamen ortadan kaldırılacaktır. Bilindiği üzere kent konseyleri içerisinde meclisler ve çalışma grupları bulunmaktadır. Kadın meclisi, çocuk meclisi, engelliler meclisi, yabancılar meclisi, vb. meclislerin yanına mahalle meclisleri adında yeni bir meclis oluşturulabilir. Bu meclis altında da her bir mahalle için alt çalışma grupları tesis edilir. Mahalle halkı tarafından belirli sayı- 
da imza toplayan ya da seçim usulü ile göreve getirilen kişiler ile mahalledeki STK temsilcileri, gönüllü temsilciler ve meslek grupları temsilcilerinden oluşan bu grupların tamamı (tüm üyeleri) da mahalle meclislerini oluşturur. Bu durumda mahallenin paydaşı olan kişiler yine mahalleleri için bir araya gelmiş olurlar. Alınan grup kararları mahalle meclisinde, mecliste alınan kararlar da belediye meclisi gündeminde yer almış olur. Bu modelde mahalle muhtarlığı tamamen ortadan kalmış oluyor. Ancak temsil, siyasal katılım vb. olumlu etkileri de varlıklarını devam ettirmiş olacaklardır.

Daha önce de belirtildiği üzere bu modeller daha da çok arttırılabilir. Ancak hiçbir değişikliğin yapılmadan mevcut durumun devam ettirilmeye çalışılması buradaki en olumsuz modelin ortaya koyabileceği dezavantajlardan çok daha fazla olumsuzluğu beraberinde getirmeye devam edecektir. Yine mahalle muhtarlıkları ile ilgili yapılacak düzenlemelerde eski düzenlemelerin tamamen iptal edilerek ayrı bir kanunda yeniden düzenleme yapılmalıdır. Daha sistematik ve bütüncül olacak bu düzenleme etkinlik ve verimliliğin artmasına ve uygulamadaki bazı belirsizliklerin ortadan kalkmasına katkı sağlayacaktır. 


\section{Extended Abstract}

\section{Historical Development and Legal Status of Neighborhood Administrations in Turkey}

\author{
Vedat Yilmaz \\ Van Yüzüncü Y1l Üniversitesi \\ ORCID: 0000-0003-4624-9824
}

\author{
Mehmet Mecek \\ Afyon Kocatepe University \\ ORCID: 0000-0001-7173-8254
}

The neighborhood is the small settlement areas where people live in communities in the city. The mukhtar, elected by residents in the neighborhood, is responsible for ensuring order and peace in the neighborhood. Through the mukhtar, neighborhood residents can bring their problems and demands on neighborhoods to the relevant central administration and local government authorities. However, they do not have the ability to directly resolve the problems that arise because they do not have their own public legal entities. Because they do not have legal personality, they can not contract, sign an agreement, be a legal entity, can not employ personnel, and most importantly they can not have a budget (financial opportunities). Therefore, they maintain their presence as a intermediary mechanism that mediate local service delivery rather than a local government. However, it constitutes the cornerstone of local governments in the development of democracy and participation culture.

Neighborhood mukhtar management consists of the mukhtar and the members. Mukhtar is an intermediate mechanism that listens to the problems of residents on behalf of the public and mobilizing central administration and local administration at the point of solving problems. The members work who are helping to the mukhtar and yet elected by the people of the neighborhood. The mukhtar and the members are elected by the neighborhood residents and are serving for five years.

The management of the mukhtar is a well-established management model with historical backgrounds from 1829 to the present day. In the historical process, it is seen that it is the name given to the very smallscale urban settlement/unit in which the neighborhoods interact with the 
same basic common feature and/or people with the same common purpose, reaching a specific number of persons or houses. This common feature or purpose is distinguished as the same religion/sect/cult, the same ethnicity, the same dynasty (phratry, clan, tribe, large nomad tent, etc.), the same profession, immigration from the same geographical region, gather around the same religious/social leader (micro-level) et. al. Nowadays, although the assets of such neighborhoods are quite high, there are more subjective common features or neighborhoods clustered around the aims draw attention.

An optimal regulatory infrastructure, an ideal organization, active organs, personnel and financial resources are needed in order to maintain the presence of the neighborhoods effectively and efficiently which is the core principle of urban area management. All these components need to be combined with the most ideal combination. With our work, we tried to shed light on the current state of the neighborhood mukhtars. However, the main goal is to provide contributions to the work of new legislation on this issue.

In Turkey, with the changes made in 2012, with major changes made in the management units, especially in the metropolitan provinces. Following the local elections in 2019, new regulatory proposals were also shared with the public by the central government officials and political partners. Therefore, it will be beneficial to integrate all these developments in the neighborhood focus with a few sample models which will affect all the managerial elements particularly the metropolitan municipality, district municipalities and neighborhood administrations. In this way, alternatives to the new possible legal regulations are presented.

A lot of models can be developed in Turkey about the neighborhood mukhtars. However, it will be preferable to be limited to a few of the political developments and expectations. In this context;

- First Model: To provide legal personality and increase the authority of the neighborhood mukhtars. As they will have a legal personality, they will have their own budgets and opportunities to spend. Yet they will have the opportunity to employ the expert personnel, make service purchases at. al. Even more contributions will be made to the development of political participation and democracy culture in the neighborhood scale. Accountability can also be increased. However, having multiple sub-legal entities within the municipal borders can lead to crisisbased differences between municipal and neighborhood mukhtars. Again, the differences in service delivery between neighborhoods can 
lead to the emergence of inequalities in the city. Again, municipalities may have the opportunity to upload their responsibilities to the neighborhood mukhtars at the point of accountability.

- The second Model: Completely eliminate the neighborhood mukhtars which do not have a legal personality and to convert it into a sub-unit of municipalities in an organic sense within municipalities. In this case, the neighborhood mukhtars will be assigned directly at the neighborhood level by the elected mayor or the elected municipal council. Mukhtars whose place, vehicle, personnel and financial resources are provided by the municipality will work much more coordinated and effective with the mayor, parliament and council. Instead of facing the two selected organs, an administrative sub-unit will be present, appointed by a chosen organ. . There will be no problems between the two units, such as political conflict, disagreement, incompatibility. However, a much more efficient system will be built at the point of use of municipal resources on the neighborhood. In this case, there will seemingly be a negative situation in the development of a culture of political mobilization, participation and democracy, as there will be no election atmosphere at the neighborhood level. However, there will be new executives with more positive features in many aspects of education, experience, etc. Moreover as political parties in this case will be at the neighborhood level there will be significant contributions to the development of culture in the neighborhood culture such as politics and political participation.

- Third Model: transformation of the neighborhood mukhtars into a separate working assembly or group in the city councils. In this case, the neighborhood mukhtars will be completely eliminated again. As is known, there are assemblies and working groups within the city councils. A new assembly called the neighborhood councils can be created along with the assembly of the women's council, the children's council, the council of the handicapped, the assembly of foreigners, etc. Under this assembly, there are also sub-working groups for each neighborhood.

All (all members) of these groups consisting of people who collect a certain number of signatures or have been recruited by the people of the neighborhood with an election, CSO representatives in the neighborhood, volunteer representatives and occupational groups create neighborhood councils. In this case, the people of the neighborhood are still come together for their neighborhoods. The group decisions taken in the neighborhood assembly, the decisions taken in the parliament are also on the agenda of the municipal council. In this model, the neighborhood 
mukhtars are completely eliminated. However, the positive effects of representation, political participation, etc. will also be maintained.

As mentioned earlier, these models can further be increased. However, attempting to continue the current situation without any change will continue to bring much more negativity than the disadvantages that the most negative model can reveal. Again, in the arrangements made regarding the neighborhood mukhtars, the old regulations should be completely canceled and rearrangement should be made in a separate law. This more systematic and holistic arrangement will contribute to the increase in effectiveness and efficiency and the elimination of certain uncertainties in practice.

\section{Kaynakça/References}

Akşit, A. (2014). Selçuklular devrinde kent iskanı ve mahalleler. Çankırı Karatekin Üniversitesi Sosyal Bilimler Enstitüsü Dergisi, 5(1), 67-88.

Arıkboğa, E. (1999). Yerel yönetimler açısından mahalle muhtarlığına bir bakış, Çă̆gdaş Yerel Yönetimler Dergisi, 8, 103- 125.

Aytaç, F. (2004), Mahalle muhtarının el kitabı, 2. Baskı, Ankara: Seçkin Yayınevi.

Bal, H., Aygül, H. H., Uysal, M. Tuna ve Oğuz, Z. N. (2012). Muhtarların sosyalekonomik özellikleri ve mahalle-kentsel sorunlara yaklaşımlan (Isparta örneği), Süleyman Demirel Üniversitesi İ̈BF Dergisi, 17(2), 17-40.

Baykara, T. (1985). Türkiye Selçukluları devrinde Konya, Ankara: Kültür ve Turizm Bakanlığı Yayınları.

Bayramoğlu A. A. (2002). Dönüşüme açllan kapı: mahalle, Yerel Yönetimler Sempozyumu Bildiriler Kitabı içinde (s. 147-166), Ankara: TODAİE Yayınları.

Braudel, F. (1993). Maddi uygarlık, ekonomi ve kapitalizm. (M. A. Kılıçbay, Çev.), Ankara: Gece Yayınları.

Bulut, Y. (2001). Mahalle muhtarlığı üzerine bir araştırma, Çă̆daş Yerel Yönetimler Dergisi, 10(3), 32-51.

Bulut, Y. ve Kara, M. (2011). Mahalle muhtarlarının kent ve mahalle güvenliğine ilişkin yaklaşımları: Antakya örneği, Mustafa Kemal Üniversitesi Sosyal Bilimler Enstitüsü Dergisi, 8(15), 1-27.

Çabuk, S. ve Demir, K. (2012). Osmanlı kentlerinde mahallelerin mekânsallaştırılabilmesi için bir yöntem denemesi: Kayseri örneği, Tarih Kültür ve Sanat Araştırmalan Dergisi (TAKSAD), 1(3), 135-153.

Çadırcı, M. (1970). Türkiye'de muhtarlık teşkilâtının kurulması üzerine bir inceleme, Belleten Dergisi, 34(135), 409- 420.

Çadırcı, M. (2007). Tanzimat sürecinde Türkiye: Ülke yönetimi, Ankara: İmge Kitabevi Yayınları.

Demirci, M. (2003). İslam'da şehir ve şehrin sosyal dinamikleri. İstem Dergisi, 1(2), 129-146.

Derbil, S. (1959). İdare hukuku. Ankara: Ankara Üniversitesi Hukuk Fakültesi Yayınları. 
Doğan, İ. (2002). Korumacilığın geleneksel kent kültüründen çıkarması gereken dersler. Ankara Üniversitesi Ĕ̆itim Bilimleri Fakültesi Dergisi. S.35(1-2), 15-23.

Düzbakar, Ö. (2003). Osmanlı döneminde mahalle ve işlevleri. Uludağ Üniversitesi FenEdebiyat Fakültesi Sosyal Bilimler Dergisi, 4(5), 97-108.

Ergenç, Ö. (1984). Osmanlı şehrindeki mahallenin işlev ve nitelikleri üzerine. Osmanlı Araştırmalan Dergisi, 4, 69-78.

Ergin, O. N. (1936). Türkiye'de şehirciliğin tarihi inkişafı. İstanbul: İstanbul Üniversitesi Hukuk Fakültesi İktisat ve İçtimaiyat Enstitüsü Neşriyatı.

Eryılmaz, B. (1988). Türkiye'de köy ve mahalle muhtarlıklarının ortaya çıkışı ve gelişimi. Türk İdare Dergisi, (378), 465- 475.

Kuban, D. (1968). Anadolu-Türk şehri tarihi gelişmesi sosyal ve fiziki özellikleri üzerinde bazı gelişmeler. Vakıflar Dergisi, 7, 53-73.

Mecek, M. ve Doğan, H. (2015). İstihdam açısından yerel yönetimlerin organizasyon yapısı ve personel yönetimi. (Editör: M. Mecek, M. Doğan, B. Parlak), İdari ve Mali Açıdan Türkiye'de Yerel Yönetimler, 211-273, Antalya: Bekad Yayınları.

Ortaylı, İ. (2000). Tanzimat devrinde Osmanl mahalli idareleri (1840-1880). Ankara: Türk Tarih Kurumu Yayınları.

Ortaylı, İ. (2013), Osmanlı toplumunda aile. İstanbul: Timaş Yayınları.

Özbilgen, E. (1987). Osmanlı toplumunda şehirler. İlim ve Sanat Dergisi, .3(17).

Özdemir, R. (1986). XIX. yüzyılın ilk yarısında Ankara. Ankara: Kültür ve Turizm Bakanlığı Yayınları.

Tanyeli, U. (1987). Anadolu-Türk kentinde fiziksel yapının evrim süreci (11.-15. yüzyll). İstanbul: İstanbul Teknik Üniversitesi Mimarlık Fakültesi Yayınları.

Üstündağ, N. (2005). Osmanli'da şehir ve şehri geliştiren unsurlardan biri olarak ayanlar: Vidin ve Rusçuk Örneği (18. Yüzyıl). Türkiyat Araştırmaları Dergisi, 2, 149-167.

Yel, A. M. ve Küçükaşcı, M. S. (2003). Mahalle, Diyanet İşleri Ansiklopedisi. Ankara: Diyanet İşleri Başkanlığı Yayınları.

5393 Sayılı Yasa. (2005). Resmi Gazete. Sayı:25874. 10 Mart 2019 tarihinde http://www.mevzuat.gov.tr/MevzuatMetin/1.5.5393.pdf adresinden erişildi.

2972 Sayılı Yasa. (1984) Resmi Gazete. Sayı:18285 10 Mart 2019 tarihinde, http://www.mevzuat.gov.tr/MevzuatMetin/1.5.2972.pdf adresinden erişildi.

4541 Sayılı Yasa. (1944). Resmi Gazete. Sayı:5682 11 Mart 2019 tarihinde, http://www.mevzuat.gov.tr/MevzuatMetin/1.3.4541.pdf, adresinden erişildi.

6360 Sayılı Yasa. (2012). Resmi Gazete. Sayı:29489 13 Mart 2019 tarihinde, http://www.mevzuat.gov.tr/MevzuatMetin/1.5.6360.pdf adresinden erişildi.

442 Sayılı Yasa. (1924). Resmi Gazete. Sayı:6813 Mart 2019 tarihinde, http://www.mevzuat.gov.tr/MevzuatMetin/1.3.442.pdf adresinden erişildi.

6552 Sayılı Yasa.(2014). Resmi Gazete. Sayı:29116. 13 Mart 2019 tarihinde, http://www.mevzuat.gov.tr/MevzuatMetin/1.5.6552.pdf adresinden erişildi.

5442 Sayılı Yasa.(1949). Resmi Gazete. Sayı:7236 14 Mart 2019 tarihinde, http://www.mevzuat.gov.tr/MevzuatMetin/1.3.5442.pdf, adresinden erişildi.

Vedat Yılmaz, 1977 Malatya ili Akçadağ ilçesi doğumludur. İlk ve orta öğrenimini Malatya ilinde tamamladı. Eylül 2005 tarihinde Anadolu Üniversitesi İktisat Fakültesi Kamu Yönetimi Bölümünden mezun oldu. Temmuz 2011 tarihinde Maltepe Üniversitesi İnsan Hakları programından mezun oldu. Şubat 2018 tarihinde Mustafa 
Kemal Üniversitesi Sosyal Bilimler Enstitüsü Kamu Yönetimi Bölümünde doktora öğrenimini tamamladı. Haziran 2012 tarihinde Öğretim Görevlisi olarak Bitlis Eren Üniversitesine atandı. Halen Van Yüzüncü Yıl Üniversitesi İ̈BF Kamu Yönetimi Bölümünde Doktor Öğretim Üyesi olarak görev yapmaktadır. Yerel Yönetimler, Kent ve Kentleşme alanlarında bilimsel çalışmalarını sürdürmektedir. YILMAZ evli ve bir çocuk babasıdır.

Vedat Yılmaz, He was born in 1977 in Akçadağ district of Malatya province. He completed his primary and secondary education in Malatya. In September 2005, he graduated from Anadolu University, Faculty of Economics, Department of Public Administration. In July 2011, she graduated from Maltepe University Human Rights Department Human Rights Program. In February 2018, he completed his $\mathrm{PhD}$ at Mustafa Kemal University, Institute of Social Sciences, Department of Public Administration. In June 2012, he was appointed to Bitlis Eren University as Lecturer. He is currently working as Assistant Prof at Van Yüzüncü Yıl University, Faculty of Economics and Administrative Sciences, Department of Public Administration. He continues his scientific studies in the field of Local Governments, Urban and Urbanization. Yllmaz is married and has one child.

E-mail: vedatyilmaz1977@gmail.com

Mehmet Mecek, 1981 yılında Alanya' da (Antalya) doğmuştur. İlk ve orta öğrenimini Alanya'da tamamlamıştır. 2001 yılında Gazi Üniversitesi önlisans Tapu ve Kadastro bölümünden mezun oldu. 2004 yılında Uludağ Üniversitesi İ̈BF Kamu Yönetimi bölümünden mezun oldu. 2015 yılında Selçuk Üniversitesi Sosyal Bilimler Enstitüsü Kamu Yönetimi Bölümünden mezun oldu. Halen Afyon Kocatepe Üniversitesinde Öğretim Görevlisi olarak görev yapmaktadır. Kamu İdareleri, Kamu Kurumları ve Kamu Personeli alanlarında bilimsel çalışmalarını sürdürmektedir. Alanya Uluslararası Yerel Yönetimler Sempozyumu düzenleme başkanlığını yapmaktadır. Mecek evli ve 2 çocuk babasıdır.

Mehmet Mecek, He was born in 1981 in Alanya (Antalya). He completed his primary and secondary education in Alanya. In 2001, he graduated from Gazi University, Associate's Deed and Cadastre Department. In 2004, she graduated from Uludağ University, Faculty of Economics and Administrative Sciences, Department of Public Administration. In 2015, he graduated from Selcuk University, Institute of Social Sciences, Department of Public Administration. He is currently working as an Instructor at Afyon Kocatepe University. He continues his scientific studies in the fields of Public Administrations, Public Institutions and Public Personnel. He is the chairman of Alanya International Local Governments Symposium. MECEK is married and has two children.

E-mail: meceklife@gmail.com 